\title{
CHROMITE COMPOSITIONS AS EVIDENCE FOR AN ARCHAEAN OPHIOLITE IN THE KUHMO GREENSTONE BELT IN FINLAND
}

\author{
JUSSI LIIPO, JOUNI VUOLLO, VESA NYKÄNEN \\ and TAUNO PIIRAINEN
}

LIIPO, JUSSI; VUOLLO, JOUNI; NYKÄNEN, VESA AND PIIRAINEN, TAUNO 1994. Chrome spinel compositions as evidence for an Archaean ophiolite in the Kuhmo greenstone belt in Finland. Bull. Geol. Soc. Finland 66, Part 1, 3-18

Investigations into chromite compositions in Archaean ultramafic rocks are rare. Most Archaean ultramafic rocks have undergone a multi-stage history of deformation and metamorphism, and therefore fresh primary chromite is rarely preserved. The preserved cores nevertheless offer a method for studying the petrogenesis of highly altered Archaean ultramafic rocks.

Hundreds of electron microprobe analyses have been performed on chrome spinels in the serpentinites from the Archaean Kuhmo greenstone belt to constrain the origin of the serpentinite massives. Best preserved chromites can be divided into two groups on the basis of their composition. Those of the first group share the characteristics of Alpine-type complexes in terms of $\mathrm{Cr} /(\mathrm{Cr}+\mathrm{Al})$ values from 0.58 to 0.76 and $\mathrm{Mg} /\left(\mathrm{Mg}+\mathrm{Fe}^{2+}\right)$ values from 0.53 to 0.60 , while those of the second type have altered to ferritchromite and have their $\mathrm{Mg} /\left(\mathrm{Mg}+\mathrm{Fe}^{2+}\right)$ values from 0.00 to 0.37 . These observations suggest that lithological unit composed of serpentinites, and pillow lavas of tholeiitic (Th1), komatiitic, and basaltic komatiitic composition, known as the Kellojärvi group, includes parts of an Archaean ophiolite

Key words: greenstone belts, serpentinite, chrome spinel, chromite, electron probe data, ophiolite, Archaean, Kuhmo, Finland

Jussi Liipo, Jouni Vuollo, Vesa Nykänen and Tauno Piirainen: Department of Geology, University of Oulu, SF-90570 Oulu, Finland 


\section{INTRODUCTION}

Chromite is an important petrogenetic indicator in ultramafic to mafic rocks. Systematic relationships exist between spinel chemistry and chemical zoning, bulk-rock composition and mineral assemblage, and geological environment and process. Chromite compositions in igneous rocks are sensitive to melt compositions, crystallization pressure and the degree of melting in the mantle source region (Irvine 1965, 1967, Dick \& Bullen 1984), while in metamorphic rocks they change with metamorphic grade (Evans \& Frost 1975, Zakrzewski 1989) and with hydrothermal alteration (Kimball 1990).

Investigations into chromite compositions in Archaean ultramafic rocks are rare, which stems from the fact that most Archaean ultramafic rocks have undergone a multi-stage history of deformation and metamorphism, and therefore fresh primary chromite is rarely preserved. The preserved cores nevertheless offer a method for studying the petrogenesis of highly altered Archaean ultramafic rocks.

Archean greenstone belts are assumed to contain remnants of ancient oceanic crust, and lithological units with oceanic crust features, such as thick pillow basalts, deep-sea sediments and massive ultramafic rocks have been thought to represent ophiolite complexes. Ophiolite complexes of Archaean age have been previously suggested by Glikson (1971), Cotterill (1979), Helmstaedt et al. (1986), and de Wit et al. (1987, 1992). Earlier some of these serpentinites have been considered to be metamorphosed cumulates of the komatiitic series (Blais et al. 1978), but on the basis of high (La/ $\mathrm{Sm})_{\mathrm{N}}$, and $(\mathrm{Sm} / \mathrm{Yb})_{\mathrm{N}}$ values, high $\mathrm{TiO}_{2}$ contents, and degree of deformation, Näätäniemi serpentinites differ from typical ultramafics of komatiitic origin (Hanski 1982, 1984, Luukkonen 1992).

The Kuhmo greenstone belt, which is one of the most intensively investigated Archaean belts in the Fennoscandian shield (Taipale et al. 1980, Piquet 1982, Piirainen 1988, Luukkonen 1992), has been divided into a number of lithostratigraphic units. The second unit in the sequence, known as the
Kellojärvi group, with massive serpentinites, pillow basalts, and deep sea sediments resembles a present oceanic crust so closely that it has been suggested that it can be an ophiolite obducted to an island arc and thus represent an Archean oceanic crust (Piirainen 1991). No sheeted dyke complex has been found, however. In order to find evidence for this hypothesis we have made a detailed petrographic and electron microprobe study of the chromites in the massive serpentinite of this group.

\section{GEOLOGICAL SETTING AND LOCATIONS}

The Kuhmo greenstone belt, surrounded by Archaean granitoids, runs N-S through eastern Kainuu for some $250 \mathrm{~km}$ in the form of a narrow, interrupted zone comprising the Suomussalmi, Kuhmo and Tipasjärvi sub-belts (Fig. 1). The Kuhmo greenstone belt underwent multi-phase deformation and metamorphism under amphibole-greenschist facies conditions (Piquet 1982, Taipale 1983, Tuisku \& Sivonen 1984, Engel \& Diez 1989).

The greenstone belt is composed principally of volcanics and subordinately of sedimentary and volcano-sedimentary rocks, which have been divided into three lithological units, each characterized by its own volcanic series (Fig 2.). The succession of supracrustal rock types begins with the 2.99 Ga old Luoma andesites (Vaasjoki \& Sakko 1991), the oldest stratigraphic unit in the Kuhmo greenstone belt. The calc-alkaline series of the Luoma group is overlain by massive serpentinites, tholeiitic (Th1) pillow lavas, pillow structure komatiites and the basaltic komatiite of the Kellojärvi group (Taipale et al. 1980). This rock unit is cross-cut by a Fe-tholeiitic dyke of age 2.79 $\mathrm{Ga}$ (Luukkonen 1988) and overlain by rhyolite, rhyodasite, Fe-tholeiite (Th2), komatiite and basaltic komatiite in a bimodal series of Ontojärvi group of $2.79 \mathrm{Ga}$ age (Piirainen 1988). Ontojärvi group is separated from the underlying Kellojärvi group by a conglomerate containing pebbles of all rock types 


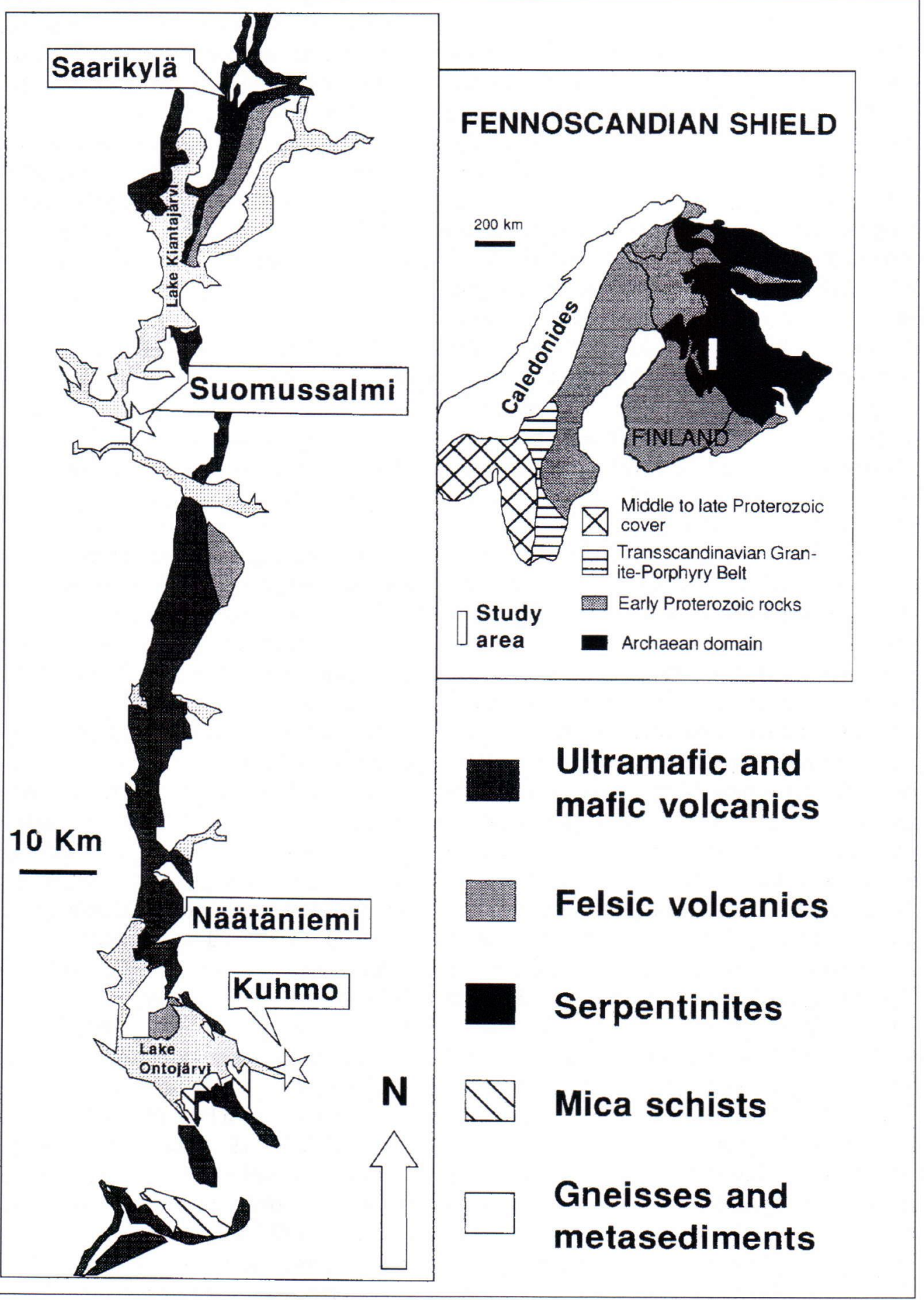

Fig 1. Geological sketch map of the Kuhmo greenstone belt, showing the locations of Näätäniemi and Saarikylä. 


\section{KUHMO GREENSTONE BELT}

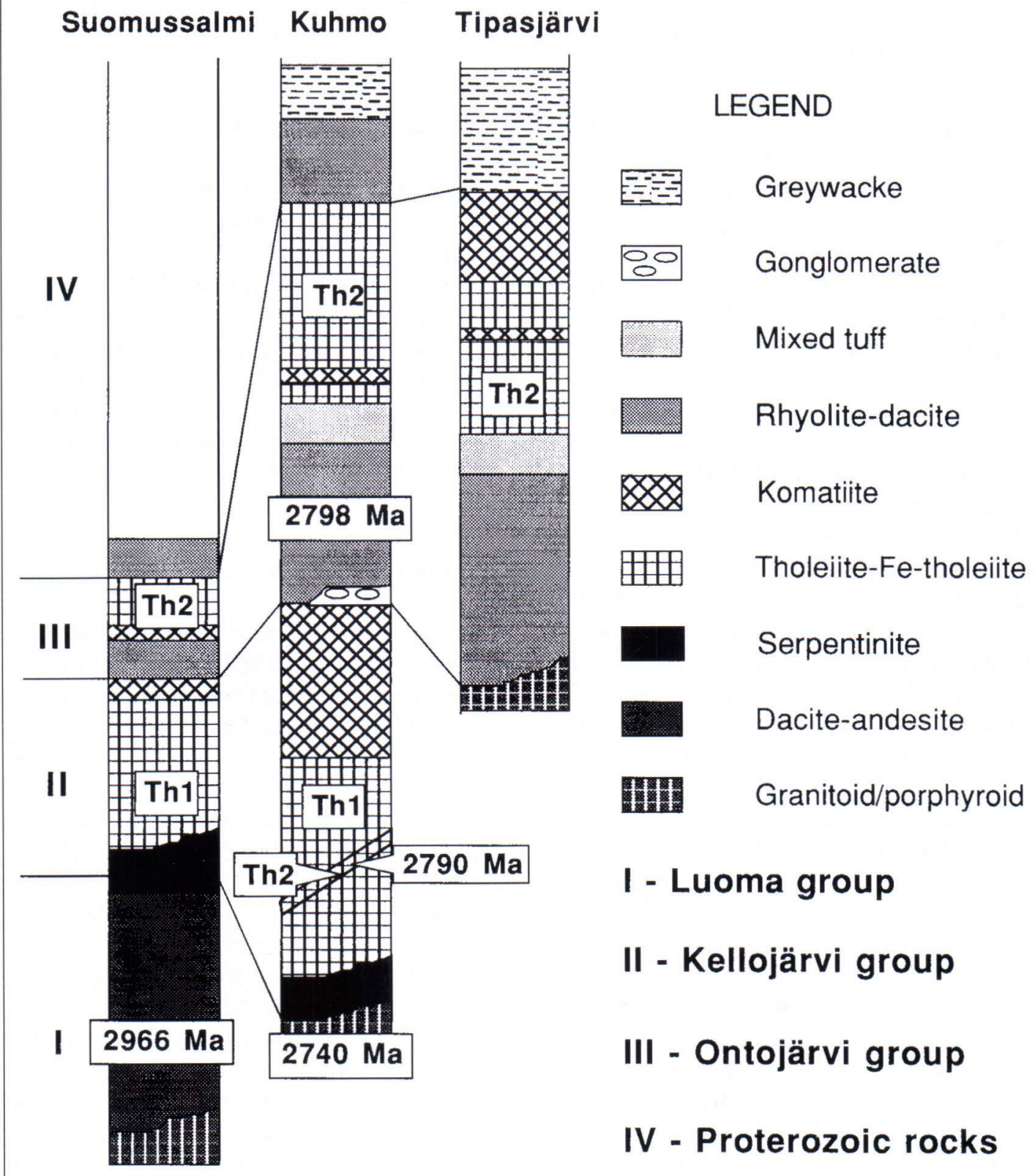

Fig. 2. Stratigraphy of the Kuhmo greenstone belt. $I=$ Luoma group, $I I=$ Kellojärvi group, $I I I=$ Ontojärvi group and $I V=$ Proterozoic rocks. Modified after Piirainen (1988). 
in the Kellojärvi group (Taipale \& Tuokko 1981).

\section{SAMPLES}

The samples for this investigation were selected from those of the Research Project on Archaean Areas (Piirainen 1991), Leinonen (1992), and from the outcrops of Näätäniemi and the Saarikylä serpentinites (Fig. 1). The Näätäniemi serpentinite massif is located in the Kuhmo sub-belt and consists of Archean serpentinites later cross-cut by an early Proterozoic differentiated dyke of age $2.2 \mathrm{Ga}$ (Hanski 1984). The Saarikylä serpentinites include two serpentinite massifs, Haaponen and Kivikangas, which are located in the Saarikylä area of the northern Suomussalmi sub-belt. Both of these massives in the Saarikylä area are small in size; the Haaponen massif has been entirely altered, and the Kivikangas massif has been altered to soapstone on its eastern margin (Leinonen 1992).

The serpentinites were originally dunites in composition, and apart from the chromites, the primary mineralogy has disappeared completely. Metamorphic olivine $\left(\mathrm{Fo}_{96}\right)$, and metamorphic pyroxene, of augitic or diopsidic composition, occurs as relict grains in some samples. The serpentinite minerals which dominate the mineralogy of the samples are antigorite and lizardite. Chromite is a ubiquitous accessory mineral in all the samples analysed. Most of the chromite occurs in the form of disseminated euhedral to subhedral crystals 20 to $400 \mu \mathrm{m}$ in diameter (Fig. 3).

\section{ANALYTICAL METHODS}

The chromites were analyzed with a JEOL JCXA 733 electron microbrobe at the Institute of Electron Optics, University of Oulu, by the method explained in detail in Alapieti \& Sivonen (1983). The analytical conditions were: accelerating voltage $15 \mathrm{kV}$, beam current $15 \mathrm{nA}$, and beam size $2 \mu \mathrm{m}$. A range of natural and synthetic standards were used, and the results were corrected with an on-line ZAF program. Iron was determined as total iron, and distributed into ferrous $\left(\mathrm{Fe}^{2+}\right)$ and ferric $\left(\mathrm{Fe}^{3+}\right)$ by the method of Carmichael (1967) based on stoichiometry. The practical detection limit in these routine analyses varies from 0.01 to $0.05 \mathrm{wt} \%$.

\section{CHROMITE CHEMISTRY}

A total of 383 electron microprobe analyses were performed on compositionally zoned chromites from the localities described above, representative analyses from which are presented in Tables 1 and 2. Chromite is the most common accessory cumulus mineral in all the serpentinite samples, and has been preserved to some extent in both areas. It has been extensively analysed to cover the full range of variations from $\mathrm{Al}$-chromite through ferritchromite to chrome magnetite.

\section{Grain-to-grain variation}

The best preserved chromites may be divided into two groups in terms of $\mathrm{MgO}$ contents. Alteration trend is characterized at first by decrease in $\mathrm{Mg}$, and subsequently in $\mathrm{Al}$ and $\mathrm{Cr}$. Chromite (I) has its $\mathrm{X}_{\mathrm{Mg}}$ $\left[\mathrm{Mg} /\left(\mathrm{Mg}+\mathrm{Fe}^{2+}\right)\right]$ value over 0.40 , (Table 1$)$ and no change has taken place in the core. In the second group, chromite (II), the grains have undergone more profound alteration, and the $\mathrm{X}_{\mathrm{Mg}}$ value ranges from 0.0 to 0.37 (Table 2). The $\mathrm{X}_{\mathrm{Cr}}[\mathrm{Cr} /(\mathrm{Cr}+\mathrm{Al})]$ value ranges from 0.58 to 0.76 in both groups.

The chromite compositions are depicted on two projections of the spinel prism in Figure 4. In bivariate plots of $\mathrm{X}_{\mathrm{Mg}}$ vs. $\mathrm{X}_{\mathrm{Cr}}$ or $\mathrm{X}_{\mathrm{Fe}}\left[\mathrm{Fe}^{3+} /\left(\mathrm{R}^{3+}\right)\right]$ (Figs. 4A, B) the chromites of the first type plot partly in the overlapping fields of Alpine and stratiform complexes, and also in the field of Alpine complexes, and those of the second group fall outside the two fields or into the field of stratiform complexes. A preference of chromite (I) for the field of alpine complexes is clearly seen in $\mathrm{X}_{\mathrm{Mg}}$ vs. $\mathrm{X}_{\mathrm{Fe}}$ diagram (Fig. 4B). 


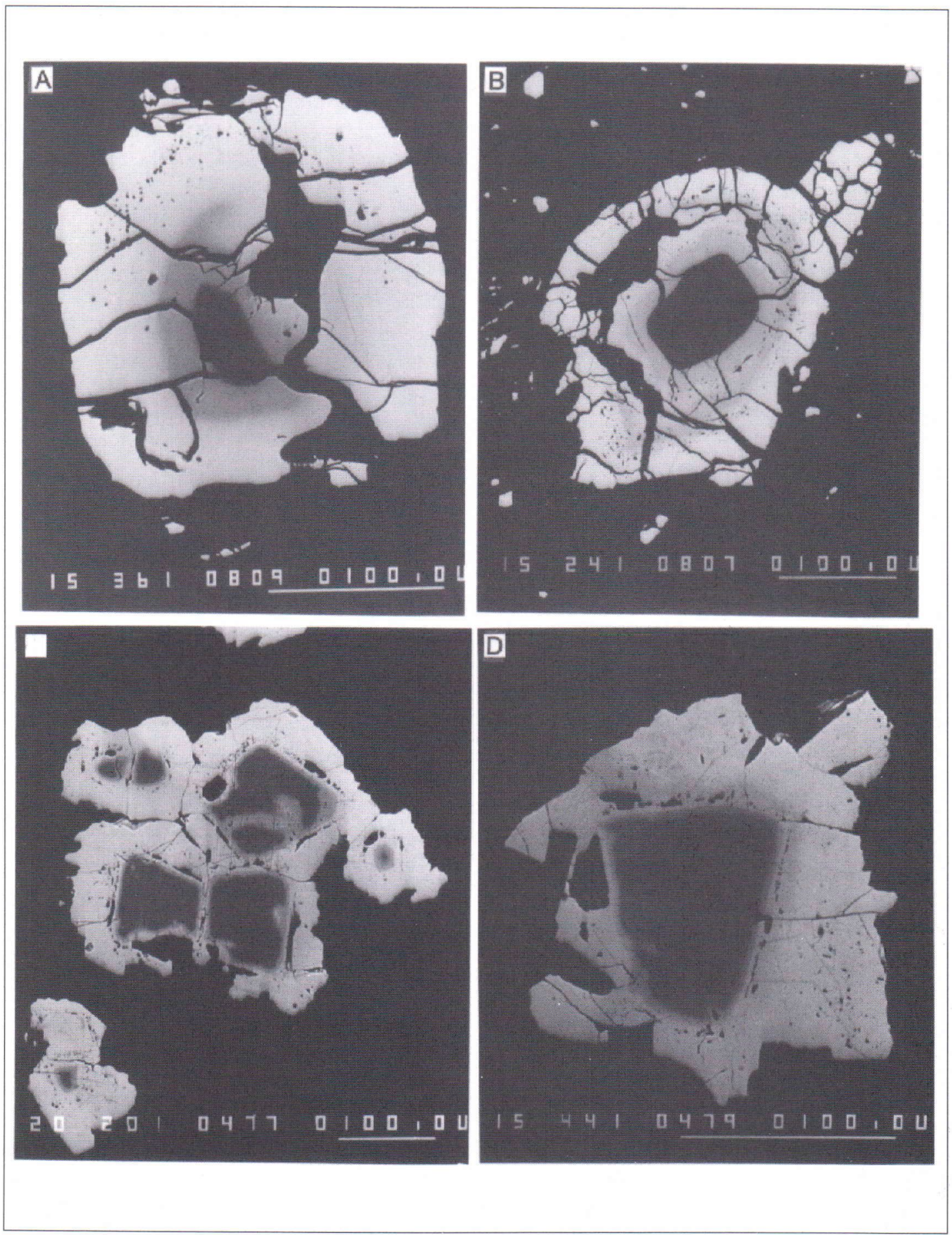

Fig. 3. BEI pictures of the zoned chromites in the serpentinites. A), B) Näätäniemi, cumulus chromite (I) grains, and C), D) Saarikylä, cumulus chromite grains (II). Each picture has a scale bar in $\mu m$ in the bottom righ. 
Table 1. Representative microprobe analyses of chromites (I) from the Näätäniemi serpentinite massif.

\begin{tabular}{lrrrrrrrrrr}
\hline & 1 & \multicolumn{1}{c}{2} & \multicolumn{1}{c}{3} & \multicolumn{1}{c}{4} & \multicolumn{1}{c}{5} & \multicolumn{1}{c}{6} & 7 & 8 & 9 & 10 \\
\hline wt\% & & & & & & & & & & \\
$\mathrm{TiO}_{2}$ & 0.36 & 0.30 & 0.27 & 0.18 & 0.19 & 0.25 & 0.56 & 0.43 & 0.06 & 0.47 \\
$\mathrm{Al}_{2} \mathrm{O}_{3}$ & 19.87 & 19.90 & 20.08 & 11.32 & 11.20 & 11.23 & 20.98 & 20.06 & 11.55 & 20.94 \\
$\mathrm{Cr}_{2} \mathrm{O}_{3}$ & 49.76 & 47.95 & 49.12 & 48.72 & 50.37 & 49.47 & 46.15 & 46.86 & 49.24 & 45.68 \\
$\mathrm{Fe}_{2} \mathrm{O}_{3}$ & 0.85 & 2.10 & 1.19 & 9.98 & 8.89 & 9.91 & 2.39 & 3.25 & 8.81 & 2.34 \\
$\mathrm{FeO}$ & 14.91 & 14.02 & 14.49 & 15.93 & 16.72 & 16.57 & 14.72 & 14.08 & 17.09 & 14.62 \\
$\mathrm{MnO}$ & 0.71 & 0.74 & 0.85 & 1.47 & 1.25 & 1.21 & 0.89 & 0.98 & 1.33 & 0.84 \\
$\mathrm{MgO}$ & 11.89 & 12.10 & 11.94 & 8.98 & 8.79 & 8.99 & 11.32 & 11.68 & 8.21 & 11.14 \\
$\mathrm{NiO}$ & 0.00 & 0.13 & 0.00 & 0.09 & 0.13 & 0.00 & 0.24 & 0.15 & 0.02 & 0.16 \\
$\mathrm{ZnO}$ & 2.52 & 2.63 & 2.44 & 2.95 & 3.10 & 3.09 & 3.48 & 3.39 & 3.16 & 3.45 \\
Total & 100.86 & 99.86 & 100.38 & 99.62 & 100.64 & 100.73 & 100.73 & 100.88 & 99.46 & 99.63
\end{tabular}

Number of ions calculated on $32(\mathrm{O})$ basis

\begin{tabular}{lllllllllll}
$\mathrm{Ti}$ & 0.0674 & 0.0560 & 0.0499 & 0.0365 & 0.0383 & 0.0487 & 0.1050 & 0.0805 & 0.0119 & 0.0889 \\
$\mathrm{Al}$ & 5.8275 & 5.8763 & 5.9038 & 3.5605 & 3.4999 & 3.5018 & 6.1622 & 5.8953 & 3.6550 & 6.2191 \\
$\mathrm{Cr}$ & 9.7890 & 9.5010 & 9.6890 & 10.275 & 10.557 & 10.346 & 9.0961 & 9.2411 & 10.452 & 9.0995 \\
$\mathrm{Fe}^{3+}$ & 0.1587 & 0.3962 & 0.2230 & 2.0028 & 1.7723 & 1.9737 & 0.4477 & 0.6091 & 1.7803 & 0.4430 \\
$\mathrm{Fe}^{2+}$ & 3.1037 & 2.9373 & 3.0232 & 3.5529 & 3.7060 & 3.6666 & 3.0676 & 2.9373 & 3.8370 & 3.0810 \\
$\mathrm{Mn}$ & 0.1490 & 0.1571 & 0.1785 & 0.3312 & 0.2815 & 0.2720 & 0.1871 & 0.2075 & 0.3016 & 0.1786 \\
$\mathrm{Mg}$ & 4.4087 & 4.5206 & 4.4397 & 3.5705 & 3.4721 & 3.5430 & 4.2076 & 4.3436 & 3.2861 & 4.1832 \\
$\mathrm{Ni}$ & 0.0000 & 0.0251 & 0.0000 & 0.0201 & 0.0285 & 0.0011 & 0.0488 & 0.0292 & 0.0034 & 0.0313 \\
$\mathrm{Zn}$ & 0.4626 & 0.4872 & 0.4503 & 0.5806 & 0.6057 & 0.6039 & 0.6403 & 0.6248 & 0.6274 & 0.6416 \\
& & & & & & & & & & \\
$\mathrm{X}_{\mathrm{Mg}}$ & 0.5869 & 0.6061 & 0.5949 & 0.5012 & 0.4837 & 0.4914 & 0.5783 & 0.5966 & 0.4613 & 0.5759 \\
$\mathrm{X}_{\mathrm{Cr}}$ & 0.6268 & 0.6179 & 0.6214 & 0.7427 & 0.7510 & 0.7471 & 0.5961 & 0.6105 & 0.7409 & 0.5940 \\
$\mathrm{Y}_{\mathrm{Fe}}{ }^{3+}$ & 0.0101 & 0.0251 & 0.0141 & 0.1265 & 0.1120 & 0.1247 & 0.0285 & 0.0387 & 0.1121 & 0.0281 \\
\hline
\end{tabular}

$$
\mathrm{X}_{\mathrm{Mg}}=\mathrm{Mg} /\left(\mathrm{Mg}+\mathrm{Fe}^{2+}\right), \mathrm{X}_{\mathrm{Cr}}=\mathrm{Cr} /(\mathrm{Cr}+\mathrm{Al}), \mathrm{Y}_{\mathrm{Fe}^{3+}}=\mathrm{Fe}^{3+} /\left(\mathrm{Fe}^{3+}+\mathrm{Cr}+\mathrm{Al}\right)
$$

The Al:Cr: $\left(\mathrm{Fe}^{3+}+2 \mathrm{Ti}\right)$ plots of the chromites are shown in Figure 5, together with their fields relative to alpine, stratiform, komatiitic and Alaskan-type complexes. Most of the analyses plot in the overlapping fields of the first two types, although lying entirely within the field of the alpine-type complexes. Figure 6 is a plot of total iron oxide (wt $\%$ ) against $\mathrm{Cr}_{2} \mathrm{O}_{3}$ with superimposed fields of alpine and stratiform chromites. Total iron ranges from $14.78 \mathrm{wt} \%$ to $17.10 \mathrm{wt} \%$ in the chromites (I), 
Table 2. Representative microprobe analyses of chromites (II) from the Näätäniemi and Saarikylä serpentinite massifs.

\begin{tabular}{|c|c|c|c|c|c|c|c|c|c|c|}
\hline & 1 & 2 & 3 & 4 & 5 & 6 & 7 & 8 & 9 & 10 \\
\hline Loc. & NN & NN & NN & NN & NN & NN & NN & SK & SK & SK \\
\hline \multicolumn{11}{|l|}{$w t \%$} \\
\hline $\mathrm{TiO}_{2}$ & 2.63 & 1.25 & 1.35 & 0.69 & 0.56 & 0.73 & 0.53 & 0.38 & 0.35 & 0.32 \\
\hline $\mathrm{Al}_{2} \mathrm{O}_{3}$ & 10.42 & 10.15 & 10.65 & 15.36 & 11.21 & 13.21 & 12.75 & 13.54 & 13.39 & 13.40 \\
\hline $\mathrm{Cr}_{2} \mathrm{O}_{3}$ & 42.35 & 48.22 & 44.56 & 44.17 & 48.98 & 45.27 & 48.90 & 49.44 & 50.13 & 49.19 \\
\hline $\mathrm{Fe}_{2} \mathrm{O}_{3}$ & 9.12 & 6.58 & 9.21 & 4.95 & 5.18 & 6.45 & 4.26 & 3.62 & 3.22 & 3.13 \\
\hline $\mathrm{FeO}$ & 26.90 & 25.63 & 25.84 & 30.45 & 30.09 & 30.32 & 30.38 & 24.55 & 26.26 & 27.53 \\
\hline $\mathrm{MnO}$ & 2.37 & 2.00 & 2.38 & 0.53 & 0.50 & 0.53 & 0.54 & 1.18 & 1.10 & 0.47 \\
\hline $\mathrm{MgO}$ & 1.82 & 2.56 & 2.10 & 1.23 & 1.26 & 1.39 & 1.35 & 4.33 & 3.71 & 2.21 \\
\hline $\mathrm{NiO}$ & 0.17 & 0.32 & 0.25 & 0.02 & 0.03 & 0.00 & 0.00 & 0.17 & 0.19 & 0.05 \\
\hline $\mathrm{ZnO}$ & 4.36 & 3.55 & 3.87 & 2.61 & 2.07 & 2.18 & 2.16 & 2.18 & 1.71 & 3.32 \\
\hline \multirow[t]{2}{*}{ Total } & 100.15 & 100.27 & 100.20 & 100.02 & 99.89 & 100.08 & 100.87 & 99.39 & 100.06 & 99.62 \\
\hline & \multicolumn{10}{|c|}{ Number of ions calculated on $32(0)$ basis } \\
\hline $\mathrm{Ti}$ & 0.5542 & 0.2632 & 0.2826 & 0.1427 & 0.1182 & 0.1519 & 0.1103 & 0.0778 & 0.0720 & 0.0660 \\
\hline $\mathrm{Al}$ & 3.4433 & 3.3347 & 3.5058 & 4.9725 & 3.7039 & 4.3125 & 4.1434 & 4.3540 & 4.2960 & 4.3706 \\
\hline $\mathrm{Cr}$ & 9.3856 & 10.632 & 9.8430 & 9.5920 & 10.852 & 9.9150 & 10.663 & 10.669 & 10.787 & 10.764 \\
\hline $\mathrm{Fe}^{3+}$ & 1.9242 & 1.3803 & 1.9364 & 1.0222 & 1.0922 & 1.3444 & 0.8838 & 0.7438 & 0.6603 & 0.6525 \\
\hline $\mathrm{Fe}^{2+}$ & 6.3047 & 5.9777 & 6.0379 & 6.9933 & 7.0532 & 7.0234 & 7.0060 & 5.6024 & 5.9763 & 6.3731 \\
\hline Mn & 0.5634 & 0.4734 & 0.5639 & 0.1238 & 0.1185 & 0.1236 & 0.1252 & 0.2725 & 0.2531 & 0.1114 \\
\hline $\mathbf{M g}$ & 0.7616 & 1.0641 & 0.8728 & 0.5031 & 0.5259 & 0.5755 & 0.5553 & 1.7610 & 1.5038 & 0.9126 \\
\hline $\mathrm{Ni}$ & 0.0373 & 0.0727 & 0.0562 & 0.0053 & 0.0076 & 0.0000 & 0.0000 & 0.0379 & 0.0421 & 0.0109 \\
\hline $\mathrm{Zn}$ & 0.9029 & 0.7316 & 0.7975 & 0.5296 & 0.4289 & 0.4450 & 0.4408 & 0.4397 & 0.3428 & 0.6789 \\
\hline $\mathrm{X}_{\mathrm{Mg}}$ & 0.1078 & 0.1511 & 0.1263 & 0.0671 & 0.0694 & 0.0757 & 0.0734 & 0.2392 & 0.2010 & 0.1253 \\
\hline $\mathrm{X}_{\mathrm{Cr}}$ & 0.7316 & 0.7612 & 0.7374 & 0.6586 & 0.7455 & 0.6969 & 0.7202 & 0.7102 & 0.7152 & 0.7112 \\
\hline $\mathrm{Y}_{\mathrm{Fe}^{3+}}$ & 0.1304 & 0.0899 & 0.1267 & 0.0656 & 0.0698 & 0.0863 & 0.0563 & 0.0472 & 0.0467 & 0.0490 \\
\hline
\end{tabular}

and from $23.02 \mathrm{wt} \%$ to $36.08 \mathrm{wt} \%$ in chromites (II). Chromites (I) plot in the overlapping fields of alpine and stratiform complexes.

\section{Within-grain variation}

The chromite grains in every sample studied were compositionally zoned and consisted of ferritchromite which had developed along the margins and within fractures in individual chromite grains (Fig. 3). Compared with the parent chromite core, the ferritchromite is enriched in $\mathrm{Mn}, \mathrm{Ti}$, and $\mathrm{Fe}^{3+}$ and depleted in $\mathrm{Mg}, \mathrm{Cr}$, and $\mathrm{Al}$. $\mathrm{Zn}$ reaches its highest values at the periphery of the chromite cores and $\mathrm{Ni}$ is distributed irregularly, though with a tendency to increase from the core to the rim.

A plot from two electron microprobe traverses is shown in Figure 7, where Fig. 7A is a chromite (I) with unaltered core from Näätäniemi and Fig. 7B a typical altered chromite (II) from Saarikylä. The trends in the $\mathrm{X}_{\mathrm{Cr}}, \mathrm{X}_{\mathrm{Mg}}, \mathrm{Zn}$ and $\mathrm{Ni}$ values correspond in both samples. Although the core of the chromite 


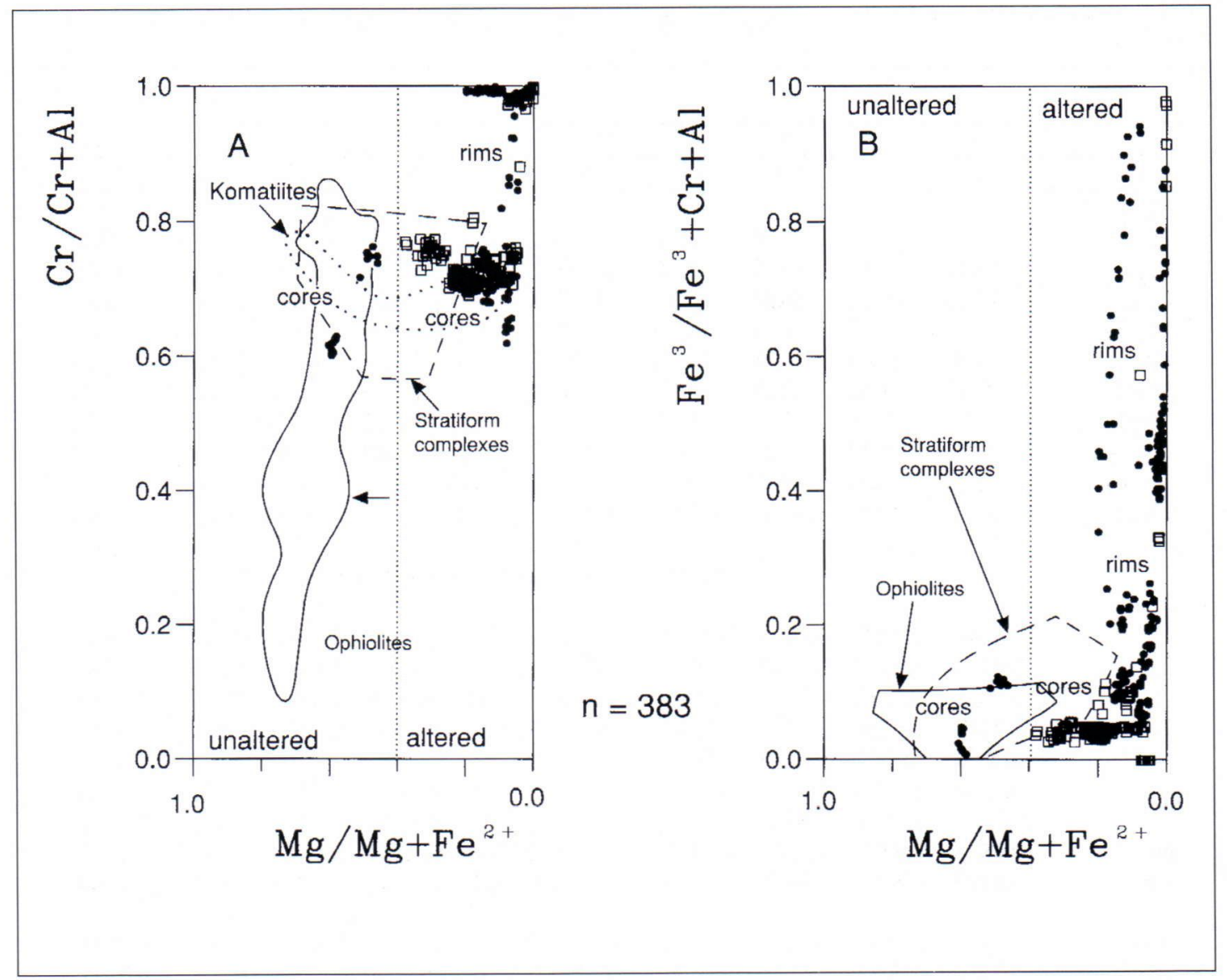

Fig. 4. Composition of chromites plotted on projections of the spinel prism of Stevens (1944). The fields for the various types of complexes shown in $A\left(\left(X_{V}\right.\right.$ vs. $\left.X_{M e}\right)$ and $B\left(X_{F e}\right.$ vs. $\left.X_{M s}\right)$ for comparison with the Näätäniemi and Saarikylä chromites are based on Irvine ( f967), Bird \& Clark (1976), Dick \& Bullen (1984) and Zhou \& Kerrich (1992). Chromites from Näätäniemi are plotted with filled dots, and those from Saarikylä with open squares.

(II) from Saarikylä has lower $\mathrm{X}_{\mathrm{Cr}}$ values than the rim, it is markedly depleted in $\mathrm{Mg}$ and enriched in $\mathrm{Cr}$ and $\mathrm{Fe}^{3+}$ relative to the unaltered chromites (I).

\section{DISCUSSION}

\section{Chemical variations of the chromites}

Chromite alteration has been studied widely (e.g. Hoffman \& Walker 1978, Kimball 1990), and has been related to hydrothermal alteration before, during, or after serpentinization, to magmatic alteration, and to regional metamorphism (Jan \&
Windley 1990). The chromite in the Näätäniemi and Saarikylä serpentinite massifs show considerable variation in $\mathrm{X}_{\mathrm{Cr}}$, and $\mathrm{X}_{\mathrm{Mg}}$, reflecting the alteration caused mainly by various stages of metamorphism (Blais \& Auvray 1990), and it may be only in the chromite (I) that the variation in $\mathrm{X}_{\mathrm{Cr}}$ is caused mainly by magmatic processes. The alteration from the chromite (I) to the chromite (II) is accompanied by almost complete elimination of $\mathrm{Mg}$ and slight loss of $\mathrm{Al}$ and $\mathrm{Cr}$. The zoned chromite grains observed (Figs. 3 and 7) suggest a greater mobility of $\mathrm{Mg}$ and $\mathrm{Al}$ with respect to $\mathrm{Cr}$. This conclusion is in agreement with the secondary hydrothermal reaction of spinels described by 
Kimball (1990). The primary composition changes related to hydrothermal alteration are an increase in $\mathrm{X}_{\mathrm{Cr}}$ and/or $\mathrm{X}_{\mathrm{Fe} 2+}\left[\mathrm{Fe}^{2+} /\left(\mathrm{Fe}^{2+}+\mathrm{Mg}\right)\right]$ Altered spinel grains associated with serpentine show an increase in $\mathrm{X}_{\mathrm{Fe} 2+}$ from the core to the rim, but may not show any increase in $\mathrm{X}_{\mathrm{Cr}}$. $\mathrm{Cr}$ is preferentially retained in spinel, during hydrothermal alteration as $\mathrm{Al}$ and $\mathrm{Mg}$ are mobilized to form amphibole and chlorite. This reaction produces spinels of lower $\mathrm{X}_{\mathrm{Mg}}$ and higher ferric iron content.

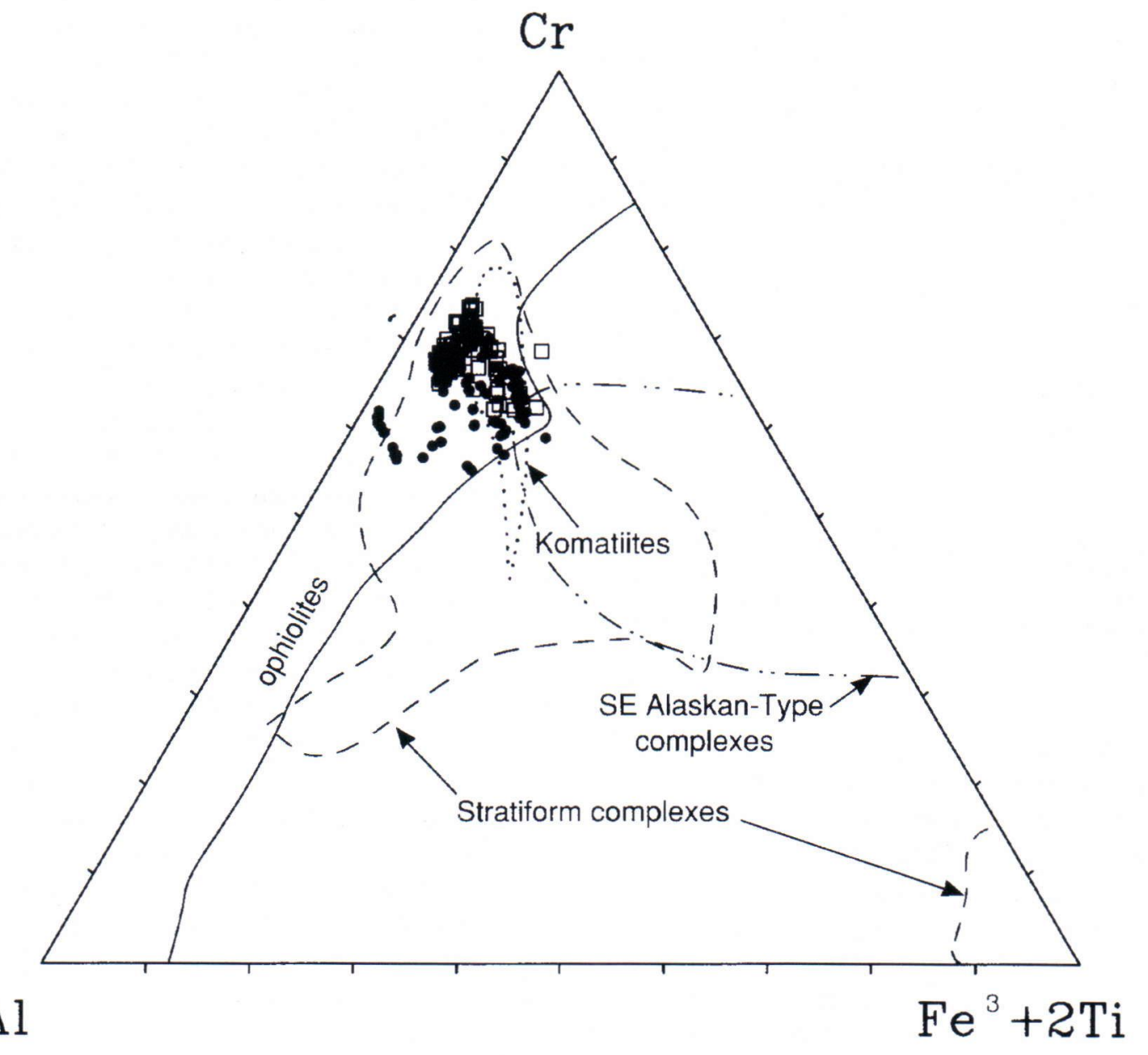

Fig. 5. Plot of $\mathrm{Cr}$-Al-Fe $\mathrm{F}^{3+} \mathrm{Ti}$ in chromites from the Näätäniemi and Saarikylä serpentinite massives compared with fields of other associations, after Jan \& Windley (1990) and Zhou \& Kerrich (1992). Chromites from Näätäniemi are plotted with filled dots, and those from Saarikylä with open squares. 


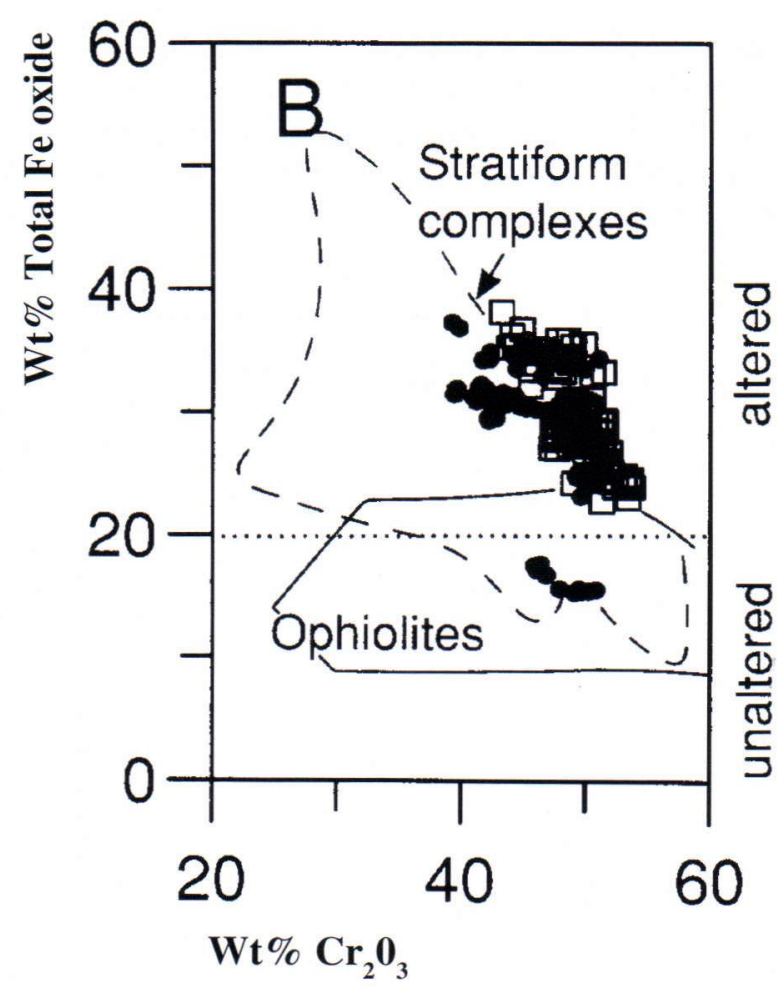

Fig. 6. Discrimination diagram for chromite composition, plotted in terms of $\mathrm{Cr}_{2} \mathrm{O}_{3}$ vs. $\mathrm{FeO}$ ( Jan \& Windley 1990). Chromites from Nä̈ätäniemi are plotted with filled dot, and from those Saarikylä with open square.

The NiO content of the unaltered chromite (I) cores is low, being bellow $0.3 \mathrm{wt} \%$, whereas that in the outer rim of the ferritchromite or $\mathrm{Cr}$-magnetite reaches $1.37 \mathrm{wt} \%$. This is attributed to the release of $\mathrm{Ni}$ from olivine during serpentinization, and the incorporation of $\mathrm{Ni}$ in magnetite and serpentine. $\mathrm{TiO}_{2}$ is correlated with $\mathrm{NiO}$ and reaches its highest values in the outer rims of the chromite grains. A $\mathrm{ZnO}$ content in excess of $0.5 \mathrm{wt} \%$ is considered significant and has been used as an indicator of mineralized ultramafic sequences (Groves et al. 1983). The $\mathrm{ZnO}$ content varies from $2.18 \mathrm{wt} \%$ to $3.47 \mathrm{wt} \%$ in the unaltered chromites, and from 0.97 wt $\%$ to $4.83 \mathrm{wt} \%$ in the ferritchromites. High $\mathrm{ZnO}$ contents of the chromites has been explained as being primary magmatic features (Groves et al. 1977, 1983) or caused by metasomatism (Wylie et al. 1987).

\section{Comparison of chromite compositions from various tectonic settings}

The chemical characteristics of chromites from various types of complexes have been widely investigated. In ophiolites, chromite occurs in cumulate complexes, tectonized peridotites and podiform chromitites (Stowe 1987), displaying as a group a wide variation in $\mathrm{X}_{\mathrm{Cr}}$ values, a smaller range of $\mathrm{X}_{\mathrm{Mg}}$ values and a lower $\mathrm{TiO}_{2}$ content than do those from stratiform complexes (Thayer 1964, Irvine 1967, Jan \& Windley 1990). These features of ophiolitic complexes are broadly shared by chromites from oceanic plutonic rocks (Dick \& Bullen 1984). Chromites in the southeast Alaskan-type complexes have higher $\mathrm{Fe}^{3+}$ and $\mathrm{Ti}$, and lower $\mathrm{Al}$ than most chromites from ophiolitic or stratiform complexes (Bird \& Clark 1976).

A distinction can be made between chromites from stratiform and podiform deposits on the basis of their $\mathrm{TiO}_{2}$ concentration. Dickey (1975) suggested $\mathrm{a} \mathrm{TiO}_{2}$ level of $0.3 \mathrm{wt} \%$ as the dividing line between these and chromites from ophiolites, but analyses with much higher $\mathrm{TiO}_{2}$ levels have been reported (Dick 1977, Auge 1987). Hérbert (1982) notes on the basis of his data on oceanic plutonic rocks that the $\mathrm{TiO}_{2}$ content of the spinels does not exceed 0.3 wt $\%$ in ultramafic tectonites, and ranges from 0.1 $\mathrm{wt} \%$ to $2.0 \mathrm{wt} \%$ in cumulate rocks. Chromites in stratiform complexes contain from $0.2 \mathrm{wt} \%$ to 2.5 wt $\% \mathrm{TiO}_{2}$ (Cameron 1979, Wilson 1982), and those in Alaskan-type complexes (Bird \& Clark 1976), and mafic-ultramafic rocks from deeper levels in island arcs contain over $0.3 \mathrm{wt} \% \mathrm{TiO}_{2}$ (Jan \& Windley 1990).

The best preserved chromites (I) from the Näätäniemi serpentinite massif have $\mathrm{X}_{\mathrm{Mg}}$ over 0.40 , and $X_{\mathrm{Cr}}$ ranging from 0.58 to 0.76 (Table 1). These ratios show an almost exact correspondence in composition with those in ophiolitic serpentinites (Vuollo \& Piirainen 1989, Haggerty 1991, Vuollo 

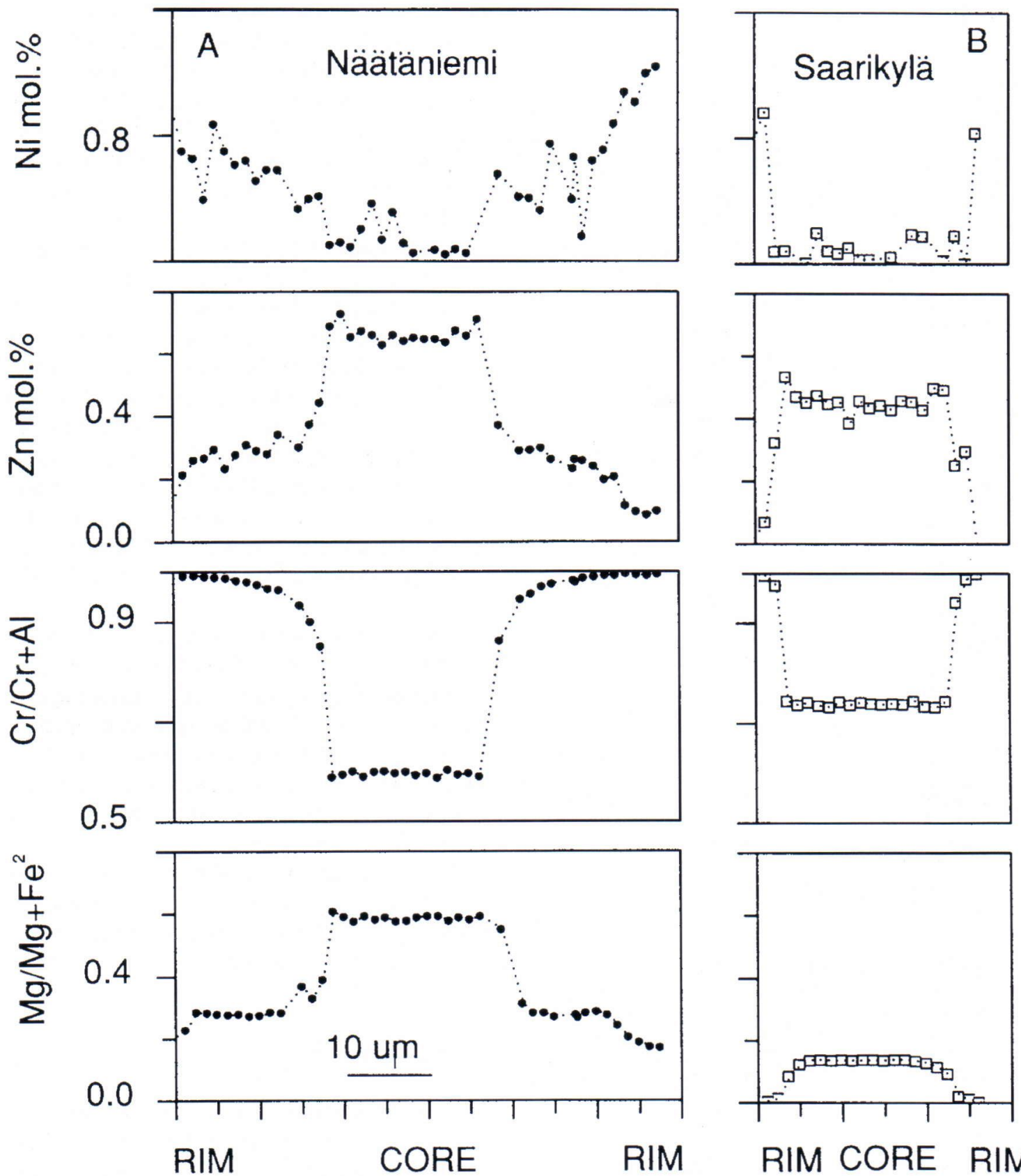

RIM CORE RIM

Fig. 7. Rim to rim compositional variations in zoned chromite grains in serpentinites from Näätäniemi A) and Saarikylä B). 


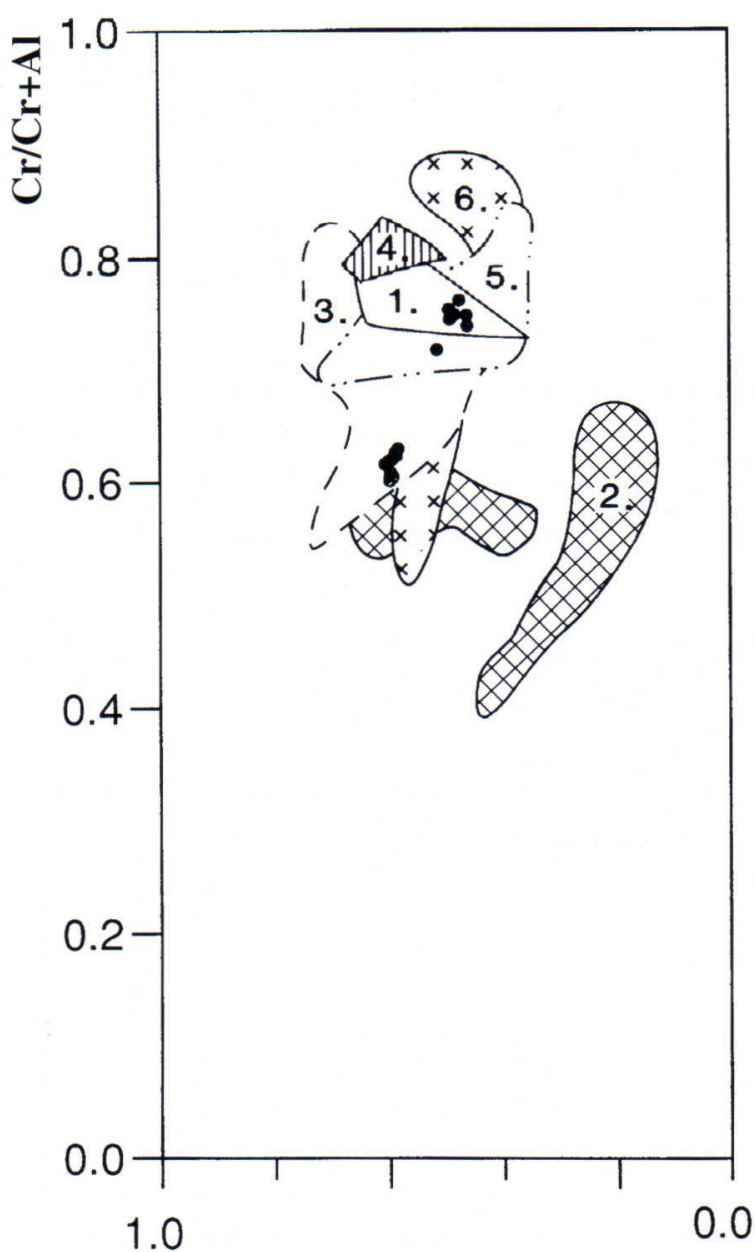

$\mathrm{Mg} / \mathrm{Mg}+\mathrm{Fe}^{2+}$

Fig. 8 Composition of chromites (I) from the Näätäniemi serpentinite massivf compared with 1) Selukwe $a$, 2) Outokumpu ${ }^{b}$ 3) Josephine ${ }^{a}$, 4) Skoumtsa-Xerolivado ${ }^{a}$,5) Vavdos and 6) New Caledonia ${ }^{a}$ ophiolite complexes $\left({ }^{b}\right.$ Vuollo \& Piirainen 1989, ${ }^{a)}$ Haggerty 1991, ${ }^{b}$ Vuollo 1994).

1994), and are distinct from those of ultramafic cumulates with a komatiitic parent magma reported earlier from Kuhmo greenstone belt, Finland, which have been suggested to be closest to a possible primary composition (Blais \& Auvray 1990), and with other occurrences from the serpentinized Archean ultramafic cumulates (Arndt 1977, Arndt et al. 1977, Groves et al. 1977, 1983, Nisbett et al. 1977, Blais \& Auvray 1990, Zhou \& Kerrich 1992) or mafic-ultramafic rocks from other geodynamic settings, by much higher $\mathrm{Al}_{2} \mathrm{O}_{3}$ (20.9 wt \%), and $\mathrm{MgO}(12.1 \mathrm{wt} \%)$ contents. Though the altered chromites (II) are comparable to those described from komatiitic cumulates by Blais and Auvray (1990).

On the basis of their $\mathrm{ZnO}$ content, chromite (I) and (II) resembles those reported from metamorphosed volcanic-type iron-nickel sulfide ores from western Australia (Groves et al. 1977, 1983, Donaldson \& Bromley 1981). However $\mathrm{Zn}$-rich chromites has been reported also from early Proterozoic Outokumpu ophiolite complex (Thayer et al. 1964, Weiser 1967, Treloar 1987, Vuollo \& Piirainen 1989), which suggest that enriched $\mathrm{Zn}$ content of chromites may be more result of metasomatism related to the $\mathrm{Zn}$-rich mineralizations than indication of komatiitic origin.

For the purposes of comparison, chemical compositions of chromites from the various ophiolite complexes (Haggerty 1991), are plotted in Figure 8 together with the chromites (I) from the present material. The unaltered chromites (I) from Näätäniemi lie in the overlapping fields of the cumulate chromites from the most ophiolite complexes.

This indicates that the ultramafic rocks of the Kellojärvi group were formed as a result of seafloor spreading followed by obduction processes, as suggested by Piirainen (1991).

\section{CONCLUSIONS}

Evidence from the chromites (I) documented here indicates that the serpentinites from the Kellojärvi group represent part of an Archaean ophiolite which have formed before $2.77 \mathrm{Ga}$. The chemical composition of the unaltered chromites (I) from the Näätäniemi serpentinite massive share the characteristics of Alpine complexes in terms of $\mathrm{X}_{\mathrm{Mg}}$ vs. $\mathrm{X}_{\mathrm{Cr}}$ and $\mathrm{X}_{\mathrm{Fe}}$ values, and $\mathrm{Cr}: \mathrm{Al}:\left(\mathrm{Fe}^{3+}+2 \mathrm{Ti}\right)$ 
relations. $\mathrm{Cr}_{2} \mathrm{O}_{3}$ below or near $50 \mathrm{wt} \%, \mathrm{Al}_{2} \mathrm{O}_{3}$ up to $21 \mathrm{wt} \%$ and moderate $\mathrm{TiO}_{2}$ content are akin to the values quoted for Alpine cumulate complexes. The altered chromites of the second type are comparable to hydrothermally altered chromites.

ACKNOWLEDGEMENTS: The samples for this study

\section{REFERENCES}

Alapieti, T. \& Sivonen, S., 1983. Use of the electron microprobe in the investigation of the Early Proterozoic Koillismaa layered igneous complex, NE Finland. Geological Survey of Finland, Report of Investigation 61, $22 \mathrm{pp}$.

Arndt, N.T., 1977. Thick, layered peridotite-gabbro lava flows in Munro Township, Ontario. Canadian Journal of Earth Sciences 14, 2620-2637.

Arndt, N.T., Naldrett, A.J. and Pyke, D.R., 1977.

Komatiitic and iron-rich tholeiitic lavas of Munro township, Northeast Ontario. Journal of Petrology 18, 319-369.

Auge, T., 1987. Chromite deposits in northern Oman ophiolite: mineralogical constrains. Mineralium Deposita 22, 1-10.

Bird, M.L. \& Clark, A.L., 1976. Microprobe study of olivine chromitites of the Goodnews Bay ultramafic complex, Alaska, and the occurrence of the platinum. U.S. Geological Survey, Journal of Research 4, 717-725.

Blais, S., Auvray, B., Capdevilla, R., Jahn, B.M., Hameurt, J. \& Bertrand, J.M., 1978. The Archaean greenstone belts of Karelia eastern Finland and their komatiitic and tholeiitic series. In Windley, B.F. \& Naqvi, S.M. (eds): Archaean geochemistry. Elsevier. Amsterdam. 87-107.

Blais, S. \& Auvray, B., 1990. Serpentinization in the Archaean komatiitc rocks of the Kuhmo greenstone belt, eastern Finland. Canadian Mineralogist 28, 55-66.

Cameron, E.N., 1979. Titanium-bearing oxide minerals of the critical zone of the eastern Bushveld Complex. American Mineralogist 64, 140-150.

Carmichael, I.S.E., 1967. The iron-titanium oxides of salic volcanic rocks and their associated ferromagnesian silicates. Contributions to Mineralogy and Petrology 14, 36-64.

Cotterill, P., 1979. The Selukwe schist belt and its chromitite deposits. Geological Society of South Africa, Special Publication 5, 229-245. were provided by the Research Project on Archaean Areas and S. Leinonen from the University of Oulu. The English manuscript was corrected by Mr. M. Hicks. We are deeply grateful to all of these people. Financial support was provided for J. Liipo by the Foundation for Research in Natural Resources in Finland. Constructive critical comments by an unknown referee are gratefully acknowledged. We also wish to thank numerous collagues whose valuable comments have improved this manuscript.

de Witt, M.J., Hart, R.A. \& Hart, R.J., 1987. The Jamestown Ophiolite Complex, Barberton mountain belt: a section through $3.5 \mathrm{Ga}$ oceanic crust. Journal of African Earth Sciences 6, 681-730.

de Witt, M.J., Roering, C., Hart, R.J., Armstrong, R.A., de Ronde, C.E.J, Green, R.W.E, Tredoux, M., Peberdy, E. \& Hart, R.A., 1992. Formation of an Archaean continent. Nature 357, 553-562.

Dick, H.J.B., 1977. Partial melting in the Josephine peridotite: 1 , The effect on mineral composition and its consequences for geobarometry and geothermometry. American Journal of Science 277, 801-832.

Dick, H.J.B. \& Bullen, T., 1984. Chromian spinel as a petrogenetic indicator in abyssal and alpine-type peridotites and spatially associated lavas. Contributions to Mineralogy and Petrology 86, 54-76.

Dickey, J.S, Jr., 1975. A hypothesis of the origin for podiform chromite deposits. Geochimica et Cosmochimica Acta 39, 1061-1074.

Donaldson, M.J. \& Bromley, G.J., 1981. The Honeymoon Well nickel sulfide deposits, Western Australia. Economic Geology 76, 1550-1564.

Engel, W.W. \& Diez, G.J., 1989. A modified stratigraphy and tectono-magmatic model for the Suomussalmi Greenstone belt, eastern Finland, based on the re-mapping of the Ala-Luoma area. Bulletin of the Geological Society of Finland 61, 143-160.

Evans, B.W. \& Frost, B.R., 1975. Chrome-spinel in progressive metamorphism - a preliminary analysis. Geochimica et Cosmochimica Acta 39, 955-972.

Glikson, A.Y., 1971. Archaean geosynclinal sedimentatio near Kalgoorlie, Western Australia. Geological Society of Australia, Special Publication 3, 443-461.

Groves, D.I., Barret, F.M., Binns, R.A. \& McQueen, K.G., 1977. Spinel Phases Associated with Metamorphosed Volcanic-Type Iron-Nickel Sulfide Ores from Western Australia. Economic Geology 72, 1224-1244.

Groves, D.I., Barret, F.M. \& Brotherton, R.H., 1983. 
Exploration significance of chrome-spinels in mineralized ultramafic rocks and nickel-copper ores. Geological Society of South Arfica, Special Publication 7, 21-30.

Haggerty, S.E., 1991. Oxide mineralogy of the upper mantle. In D.H. Lindsley (ed.) Oxide minerals: Petrologic and magnetic significance. Reviews in Mineralogy 25, 355-416.

Hanski, E., 1982. Albiittidiabaasit ja niihin liittyvät ultramafiset kivet Kuhmon ja Kolin alueilla. Summary: A comprative study of albite diabases and related ultramafic rocks in the Kuhmo and Koli areas, eastern Finland. Arkeeisten alueiden malmiprojekti, Raportti No 6. University of Oulu. 75 pp. (in Finnish with English summary).

Hanski, E., 1984. The gabro-wherlite association in the eastern part of the baltic schield. Phil.-Lic.-thesis, University of Oulu. $78 \mathrm{pp}$.

Helmstaedt, H., Padgham, W.A. \& Brophy, J.A., 1986. Multiple dikes in Lower Kam Group, Yellowknife greenstone belt: Evidence for Archean sea-floor spreading. Geology 14, 562-566.

Hérbert, R., 1982. Petrography and mineralogy of ocean peridotites and gabbros; some comparisions with ophiolite examples. Ofioliti 7, 299-324.

Hoffman, M.A. \& Walker, D., 1978. Textural and chemical variations of olivine and chrome spinel in the East Dover Ultramafic Bodies, South-Central Vermont. Geological Society of America, Bulletin 89, 699-710.

Irvine, T.N., 1965. Chromian spinel as a petrogenetic indicator Part 1. Theory. Canadian Journal of Earth Sciences 2, 648-672.

Irvine, T.N., 1967. Chromian spinel as a petrogenetic indicator Part 2. Petrologic applications. Canadian Journal of Earth Sciences 4, 71-103.

Jan, M.Q. \& Windley, B.F., 1990. Chromian

Spinel-Silicate Chemistry in Ultramafic Rocks of the Jijal Complex, Northwest Pakistan. Journal of Petrology 31, 667-715.

Kimball, K.L., 1990. Effects of hydrothermal alteration on the compositions of chromian spinels. Contributions to Mineralogy and Petrology 105, 337-346.

Leinonen, S., 1992. Suomussalmen, Haaposen ja Kivikankaan vuolukivien geologia ja soveltuvuus hyötykäyttöön. M.Sc.-thesis, University of Oulu. (in Finnish). $111 \mathrm{pp}$.

Luukkonen, E.J., 1988. The structure and stratigraphy of the northern part of the late Archaean Kuhmo greenstone belt, eastern Finland. In E. Marttila (ed.): Archean geology of the Fennoscandian Shield. Geological Survey of Finland, Special Paper 4, 71-96.

Luukkonen, E.J., 1992. Late Archean and early Proterozoic structural evolution in the Kuhmo-Suo- mussalmi terrain, eastern Finland. Anneales Universitas Turkuensis, Ser.A.II. 37 pp.

Nisbet, E.G., Bickle, M.J. and Martin, A., 1977. The mafic and ultramafic lavas of the Belingwe greenstone belt, Rhodesia. Journal of Petrology 18, 521-566.

Piirainen, T., 1988. The geology of the Archaean greenstone-granitoid terrain in Kuhmo, eastern Finland. In Marttila, E. (ed.): Archean geology of the Fennoscandian Shield. Geological Survey of Finland, Special Paper 4, 39-51.

Piirainen, T.A., 1991. Arkeeinen geologinen evoluutio ja malminmuodostus . In Piirainen, T.A. \& Vuollo, J.I (eds): Arkeeinen ja proterotsooinen geologinen evoluutio ja malminmuodostus. Pohjois-Karjalan malmiprojektin loppuraportti. 31. University of Oulu. 63-69. (in Finnish).

Piquet, D., 1982. Mécanismes de recristallisations métamorphiques dans les ultrabasites: example des roches vertes archéennes de Finlande orientale (Ceinture de Suomusalmi - Kuhmo). These de $3^{\text {eme }}$ cycle, Université de Rennes, France. 264 pp.

Stevens, R.E., 1944. Composition of some chromites of the western hemisphere. American Mineralogist 29, 1-34.

Stowe, C.W., 1987. Evolution of chromium ore fields. Van Nostrand Reinhold Company, New York. 340 pp.

Taipale, K., 1983. The geology and geochemistry of the Archaean Kuhmo greenstone-granite terrain in the Tipasjärvi area, eastern Finland. Acta Universitas Ouluensis, A 151, 98 pp.

Taipale, K.\& Tuokko, I., 1981. Kuhmon arkeeisen vihreäkivivyöhykkeen geologiasta ja malmimineralisaatioista. Kuhmon ja Kittilän malmiprojektit, Raportti No 47, University of Oulu, 65 pp.(in Finnish)

Taipale, K., Tuokko, I. \& Piirainen, T., 1980. A brief introduction in the geology and geochemistry of the Kuhmo greenstone belt, eastern Finland. In Papunen, H. (ed.): Nickel Sulfides in Ultramafic and Mafic Rocks, IGCP project 161, Field excursion guidebook, 37-73.

Thayer, T.P., 1964. Principal features and origin of podiform chromite deposits, and some observations on the Gulemon-Soridag district, Turkey. Economic Geology 59, 1497-1524.

Thayer, T.P., Milton, C., Dinnin, J. \& Rose, H., 1964. Zincian chromite from Outokumpu, Finland. American Mineralogist 49, 1178-1183.

Treloar, P.J., 1987. The Cr-minerals of Outokumpu theirchemistry and significance. Journal of Petrology 28, 867-886.

Tuisku, P. \& Sivonen, S., 1984. Paine- ja lämpötilaolosuhteet Kuhmon vihreäkivivyöhykkeen metamorfoosissa. Summary: Geothermometry, geobarometry 
and metamorphic conditions in the Kuhmo greenstone belt. Arkeeisten alueiden malmiprojekti, Raportti No 19. University of Oulu. 65 pp. ( in Finnish with English summary).

Vaasjoki, M. \& Sakko, M., 1991. Isotopic constraints on the age and genesis of the Finnish greenstone belts and their ore deposits: Soviet - Finnish Symposium, Kostomuksha, 15-16.

Vuollo, J., 1994. Palaeoproterozoic basic igneous events in Eastern Fennoscandian Shield between 2.45 $\mathrm{Ga}$ and $1.97 \mathrm{Ga}$, studied by means of mafic dyke swarms and ophiolites in Finland. Acta Universitas Ouluensis, A 250, 48 pp.

Vuollo, J. \& Piirainen, T., 1989. Mineralogical evidence for an ophiolite from the Outokumpu serpentinites in north Karelia, Finland. Bulletin of the Geological Society of Finland, 61, 95-112.

Weiser, T., 1967. Zink- und Vanadium-führende
Chromite von Outokumpu, Finland. Neues Jahrbuch für Mineralogie, Mh. 234-243.

Wilson, A.H., 1982. The geology of the Great 'Dyke', Zimbabwe: the ultramafic rocks. Journal of Petrology 23, 240-292.

Wylie, A.G., Candela, P.A. \& Burke, T.M., 1987. Compositional zoning in unusual $\mathrm{Zn}$-rich chromite from the Sykesville district of Maryland and its bearing on the orgin of the "ferritchromit". American Mineralogist 72, 413-422.

Zakrzewski, M., 1989. Chromian spinel from Kusa, Bergslagen, Sweden. American Mineralogist 74, 448-455.

Zhou, M-F. \& Kerrich, R., 1992. Morphology and composition of chromite in komatiites from the Belingwe greenstone belt, Zimbabwe. Canadian Mineralogist 30, 303-317. 